\title{
RPSA wt Allele
}

National Cancer Institute

\section{Source}

National Cancer Institute. RPSA wt Allele. NCI Thesaurus. Code C51313.

Human RPSA wild-type allele is located in the vicinity of 3p22.2 and is approximately $6 \mathrm{~kb}$ in length. This allele, which encodes $40 \mathrm{~S}$ ribosomal protein SA, plays a role in a variety of biological processes that are mediated by interactions with cell surface receptors. 